\title{
Books Received / Livres reçus
}

Atlas, Allan W. La Musique de la Renaissance en Europe (1400-1600). Centre d'études supérieures de la Renaissance, Collection "Épitome musical ». Tournhout: Brepols, 2011. xxix, 995 p. + 113 ill. ISBN 978-2-503-54397-0 (relié) $75 €$.

Bellitto, Christopher and David Zachariah Flanigin (eds.). Reassessing Reform: A Historical Investigation into Church Renewal. Washington, DC: The Catholic University of America Press, 2012. Pp. xii, 289. ISBN 978-0-8132-1999-8 (hardcover) \$69.95.

Bénévent, Christine, Annie Charon, Isabelle Diu et Magali Vène (eds.). Passeurs de textes. Imprimeurs et libraires à l'âge de l'Humanisme. Études et rencontres de l'École de Chartres, 37. Paris: École de Chartres, 2012. 306 p. ISBN 978-2-35723-029-3 (broché) $34 €$.

Bokdam, Sylviane. Métamorphoses de Morphée. Théories du rêve et songes poétiques à la Renaissance, en France. Bibliothèque littéraire de la Renaissance, 86. Paris: Honoré Champion, 2012. 1185 p. ISBN 978-2-7453-2356-9 (relié) $194.75 €$.

Bruscambille. Oeuvres complètes. Les Fantaisies. Les nouvelled et plaisantes Imaginations. Facecieuses Paradoxes. Les plaisants Paradoxes. Pamphlets. Édition critique par Hugh Roberts et Annett Tomarken. Textes littéraires de la Renaissance, 15. Paris: Honoré Champion, 2012. 820 p. ISBN 9782745324917 (relié) $153.75 €$.

Carty, Jarrett A. Divine Kingdom, Holy Order: The Political Writings of Martin Luther. Saint Louis: Concordia Publishing House, 2012. Pp. xi, 525. ISBN 978-0-7586-2711-7 (hardcover) \$59.99.

Cary, Elizabeth. The Mirror of the Worlde: A Translation by Elizabeth Tanfield Cary. Edited with an introduction by Lesley Peterson. Montreal and Kingston: McGill-Queen's University Press, 2012. Pp. xii, $248+13$ ill. ISBN 978-0-773-540729 (hardcover) \$95.

Cicali, Gianni. L'Inventio crucis nel teatro rinascimentale fiorentino. Una leggenda tra spettacolo, antisemitismo e propaganda. Firenze: Società Editrice Fiorentina, 2012. Pp. 181. ISBN 978-88-6032-233-3 (paperback) € 15. 
Creasman, Allyson F. Censorship and Civic Order in Reformation Germany, 1517-1648: "Printed Poison \& Evil Talk." St Andrews Studies in Reformation History. Farnham, UK and Burlington, VT: Ashgate, 2012. Pp. x, $282+4$ ill. ISBN 978-1-4094-1001-0 (hardcover) \$119.95.

Dailey, Alice. The English Martyr from Reformation to Revolution. Notre Dame, IN: University of Notre Dame Press, 2012. Pp. xvi, 332. ISBN 978-0-02612-7 (paperback) \$38.

de La Boétie, Étienne. Discourse on Voluntary Solitude. Trans. James B. Atkinson and David Sices. Introduction and notes by James B. Atkinson. Indianapolis and Cambridge: Heckett Publishing Company, 2012. Pp. xlix, 46. ISBN 978-1-60384-839-8 (paperback) \$7.95.

Demonet, Marie-Luce et Stéphan Geonget (éds.). Un joyeux quart de sentences. Études Rabelaisiennes, 52. Genève: Librairie Droz, 2012. 190 p. ISBN 978-2-600-01607-0 (relié) 84 \$.

Denbo, Michael. The Holgate Miscellany: An Edition of Pierpont Morgan Library Manuscript, MA 1057. Medieval and Renaissance Texts and Studies 438 / Renaissance English Text Society, $7^{\text {th }}$ series, vol. 35. Tempe, AZ: ACMRS in conjunction with Renaissance English Text Society, 2012. Pp. xxiii, 358. ISBN 978-0-86698-486-7 (hardcover) \$85.

de Seyssel, Claude. La Monarchie de France. Texte établi et présenté par Renzo Ragghianti. Société des textes français modernes, 247. Paris: Classiques Garnier, 2012. 190 p. ISBN 978-2-8124-1077-2 (broché) $20 €$.

Dickerson III, D. D., Anthony Sigel, and Ian Wardropper (eds.). Bernini: Sculpting in Clay. With contributions by Andrea Bacchi, Tomaso Montanari, and Steven F. Ostrow. New York: The Metropolitan Museum of Art, New York / New Haven and London: Yale University Press, 2012. Pp. xvi, $416+472$ ill. ISBN 978-0-300-18500-3 (hardcover) $\$ 65$.

Dillon, Anne. Michelangelo and the English Martyrs. Farnham, UK, and Burlington, VT: Ashgate, 2012. Pp. xxvii, $356+81$ ill. ISBN 978-0-75466647-5 (hardcover) \$134.95.

Du Gardin, Louis. Les Premières Addresses du chamin de Parnasse. Édition critique par Emmanuel Buron et Guillaume Peureux. Paris: Classiques Garnier, 2012. 328 p. ISBN 978-2-8124-0390-3 (broché) $38 €$.

Eisenbichler, Konrad. L'opera poetica di Virginia Martini Salvi (Siena, c. 1510 - Roma, post 1571). Monografie di storia e letteratura 
senese 17. Siena: Accademia degli Intronati di Siena, 2012. Pp. 221 ISBN 978-88-89073-18-6 (paperback) € 16.

Gaposchkin, M. Cecilia (ed.). Blessed Louis the Most Glorious of Kings: Texts Relating to the Cult of Saint Louis of France. Trans M. Cecilia Gaposchkin with Phyllis B. Katz. Notre Dame, IN: University of Notre Dame Press, 2012. Pp. xi, 307. ISBN 978-0-268-02984-5 (paperback) \$39.

Hammill, Graham. The Mosaic Constitution: Political Theology and Imagination from Machiavelli to Milton. Chicago: University of Chicago Press, 2012. Pp. xii, 328. ISBN 978-0-226-31542-3 (hardcover) \$45.

Hampton, Bryan Adams. Fleshly Tabernacles: Milton and the Incarnational Poetics of Revolutionary England. Notre Dame, IN: University of Notre Dame Press, 2012. Pp. x, 374. ISBN 978-0-268-03096-4 (paperback) \$40. Henderson, Judith Rice (ed.). The Unfolding of Words: Commentary in the Age of Erasmus. Toronto: University of Toronto Press, 2012. Pp. xxi, 278. ISBN 978-1-4426-4337-6 (hardbound) \$65.

Hessus, Helius Eobanus. The Poetic Works of Helius Eobanus Hessus. Vol. 3, King of Poets, 1514-1517. Ed., trans., and annot. by Harry Vredeveld. The Renaissance Society of America, Texts and Studies Series. Leiden and Boston: Brill, 2012. Pp. xxiii, 786 + 19 ill. ISBN 978-90-04-22893-1 (hardcover) \$199.

Holmes, Peter (ed.). Caroline Casuistry: The Cases of Conscience of Fr Thomas Southwell SJ. Catholic Record Society Publications 84. Rochester, NY: The Boydell Press, 2012. Pp. 1, 308. ISBN 978-0-902832-27-5 (hardcover) $\$ 80$.

Jackson, Ken and Arthur F. Marotti (eds.). Shakespeare and Religion: Early Modern and Postmodern Perspectives. Notre Dame, IN: University of Notre Dame Press, 2011. Pp. 306. ISBN 978-0-268-03270-8 (paperback) $\$ 38$.

Ker, James and Jessica Winston (eds.). Elizabethan Seneca: Three Tragedies. MHRA Tudor \& Stuart Translations 8. London: Modern Humanities Research Association, 2012. Pp. ix, 340. ISBN 978-0-947623-28-2 (paperback) \$20.

Lee, Christina H. (ed.). Western Visions of the Far East in a Transpacific Age, 1522-1657. Transculturalisms, 1400-1700. Farnham, UK and Burlington, VT: Ashgate, 2012. Pp. xiii, 227 + 17 ill. ISBN 978-1-40940850-5 (hardcover) \$104.95. 
Lemonnier-Lesage, Virginie et Marie Roig Miranda (éds.). Réalités et représentations de la justice dans l'Europe des XVIe et XVIIe siècles. "Europe XVI-XVII» 17. Nancy: Groupe "XVIe et XVIIe siècles en Europe», Université de Lorraine, 2012. 225 p. ISBN 978-2-917030-06-6 (broché) $16 €$.

Lepage, John L. The Revival of Antique Philosophy in the Renaissance. New York: Palgrave Macmillan, 2012. Pp. xv, $281+14$ ill. ISBN 978-1-137-28161-4 (hardcover) $\$ 85$.

Marguerite de Navarre. Oeuvres Complètes, sous la direction de Nicole Cazauran. Tome V. L'Histoire des Satyres, et Nymphes de Dyane. Les Quatre Dames et les quatre Gentilzhommes. La Coche. Édition critique établie, présentée et annotée par André Gendre, Loris Petris et Simone de Reyff. Textes littéraires de la Renaissance, 11. Paris: Honoré Champion, 2012. 454 p. ISBN 978-2-7453-2390-3 (relié) $105 €$.

Martin, Jessica and Alec Ryrie (eds.). Private and Domestic Devotion in Early Modern Britain. St Andrews Studies in Reformation History. Farnham, UK and Burlington, VT: Ashgate, 2012. Pp. xi, $285+11$ ill. ISBN 978-14094-3131-2 (hardcover) \$134.95.

Mayer, Thomas F. (ed.). Reforming Reformation. Farnham, UK and Burlington, VT: Ashgate, 2012. Pp. xiv, $251+14$ ill. ISBN 978-1-4094-5154-9 (hardcover) \$119.95.

Michelson, Emily, Scott K. Taylor, and Mary Noll Venables (eds.). A Linking of Heaven and Earth: Studies in Religious and Cultural History in Honor of Carlos M.N. Eire. St Andrews Studies in Reformation History. Farnham, UK and Burlington, VT: Ashgate, 2012. Pp. xi, 250 ISBN 978-1-40943943-1 (hardcover) \$124.95.

Paleotti, Gabriele. Discourse on Sacred and Profane Images. Trans. William McCuaig, with intro. by Paolo Prodi. The Getty Research Institute Text \& Documents. Los Angeles: The Getty Research Institute, 2012. Pp. xiv, $353+11$ ill. ISBN 978-1-60606-116-9 (paperback) \$60.

Popper, Nicholas. Walter Ralegh's History of the World and the Historical Culture of the Late Renaissance. Chicago and London: The University of Chicago Press, 2012. Pp. xvi, $350+19$ ill. ISBN 978-0-226-67500-8 (hardcover) $\$ 55$.

Racine St-Jacques, Jules. L'honneur et la foi. Le droit de résistance chez les Réformés français (1536-1581). Cahier d'Humanisme et Renaissance, 
107. Genève: Librairie Droz, 2012. 218 p. ISBN 978-2-600-01587-5 (broché) $57.60 \$$.

Radisson, Pierre-Esprit. The Collected Writings. Vol. 1. The Voyages. Ed. Germaine Warkentin. Montreal and Kingston: McGill-Queen's University Press / Toronto: The Champlain Society, 2012. Pp. xvii, $357+$ 7 ill., 5 maps. ISBN 978-0773540828 (hardcover) \$65.

Roudaut, François (éd.). Religion et littérature à la Renaissance. Mélanges en l'honneur de Franco Giacone. Bibliothèque de la Renaissance, 8. Paris: Classiques Garnier, 2012. 910 p. ISBN 978-2-8124-0807-6 (relié) $98 €$.

Rouget, François. Ronsard et le livre (II). Étude de critique génétique et d'histoire littéraire. Seconde partie: Les livres imprimés. Cahiers d'Humanisme et Renaissance, 109. Genève: Librairie Droz, 2012. 742 p. ISBN 978-2-600-01540-0 (broché) 78 \$.

Schlitt, Melinda (ed.). Gifts in Return: Essays in Honour of Charles Dempsey. Essays and Studies 30. Toronto: Centre for Reformation and Renaissance Studies, 2012. Pp. 490 + 95 ill. ISBN 978-0-7727-2130-3 (paperback) \$37. Sciacca, Christine (ed.). Florence at the Dawn of the Renaissance: Painting and Illumination, 1300-1350. Los Angeles: The J. Paul Getty Museum, 2012. Pp. xix, $426+240$ ill. ISBN 978-1-60606-126-8 (hardcover) \$65.

Spearing, A.C. Medieval Autographies: The "I" of the Text. Notre Dame, IN: University of Notre Dame Press, 2012. Pp. viii, 347. ISBN 978-0-26801782-8 (paperback) \$32.

Welch, Anthony. The Renaissance Epic and the Oral Past. New Haven and London: Yale University Press, 2012. Pp. viii, 260. ISBN 978-0-30017886-9 (paperback) \$40. 